\title{
DEWATS for urban Nepal: a comparative assessment for community wastewater management
}

\author{
LAURA BRIGHT-DAVIES, CHRISTOPH LÜTHI and \\ ALEXANDER JACHNOW
}

This paper provides a comparative assessment of community-scale decentralized wastewater treatment systems (DEWATS) in Nepal, based on three communities in urban and peri-urban locations. The analysis provides lessons for sustainable and future replications of this approach, highlighting the benefits, drivers for long-term operation and maintenance, and barriers associated with up-scaling. Nepal is experiencing the fastest rate of urbanization in the South Asian region, while sanitation and wastewater management are emerging as some of the biggest challenges in urban areas. Over 43 per cent of the population still lacks access to a toilet, and virtually all wastewater and septage is discharged into water bodies without treatment. These mounting problems of urban sanitation demand urgent and appropriate solutions. The inherent simplicity of DEWATS provides an effective, affordable, and low-maintenance option for treating wastewater. This is particularly the case for low-income communities.

Keywords: urban, community participation, decentralized sanitation

ADEQUATE SANITATION AND WASTEWATER TREATMENT, or the lack thereof, has reached a point of crisis within many rapidly growing cities of the developing world. Population growth combined with increasing urbanization simply exacerbates this phenomenon. More than 50 per cent of the global population already reside in towns and cities (UNFPA, 2007), with most of this growth occurring within the Asian regions. These rapidly growing urban settlements present the greatest need for improved sanitation. In South Asia alone, almost 1 billion people are lacking access to adequate sanitation and hygiene services (World Bank, 2012).

In the South Asian country of Nepal, this situation is no exception, especially in urban areas. With a population estimated at 26.5 million, Nepal is experiencing rapid urban growth at the rate of 5 per cent, making it the highest rate of urbanization

Laura Bright-Davies (laura.davies@gmail.com) was a postgraduate researcher in Nepal and India working for the GFA Municipal Support Team in Kathmandu (on behalf of GIZ Nepal).

Dr Christoph Lüthi (christoph.luethi@eawag.ch) is a senior scientist at EAWAG's department for Water and Sanitation in Developing Countries (SANDEC).

Dr Alexander Jachnow (a.jachnow@ihs.nl) was the team leader for GFA Consulting Group's Municipal Support Team in Kathmandu Nepal, within GIZ Nepal's SUNAG Programme.

The authors acknowledge support from GIZ Nepal's SUNAG Programme; Government of Nepal's DUDBC and DWSS; GFA Consulting Group's MST; EAWAG/SANDEC; and Nepalese experts from UN-HABITAT, ENPHO, WaterAid, and SNV.

(C) Practical Action Publishing, 2015, www.practicalactionpublishing.org http://dx.doi.org/10.3362/1756-3488.2015.012, ISSN: 0262-8104 (print) 1756-3488 (online) 
in the South Asian subcontinent (Muzzini and Aparicio 2013). Combined with the government's inability to provide sufficient infrastructure and services, this means the country's urban environments are already struggling to cope. The majority of wastewater and septage is simply discharged into rivers and water-bodies without any form of treatment. Kathmandu's Bagmati River carries thousands of cubic metres of raw sewage and industrial effluent through the nation's capital and onwards to India.

Conventional approaches to wastewater treatment, such as centralized systems, have largely failed to address sanitation needs in Nepal. Since the 1980s, a number of sewer systems and treatment plants based on Western models have been constructed, but with limited success (Tuladhar et al., 2008). Of the four centralized sewerage treatment systems constructed in Kathmandu, not one is effectively operating today (ibid.). Citizens and municipalities are simply unable to afford the high capital investment, associated connection rates, and the operation and maintenance $(\mathrm{O} \& \mathrm{M})$ provision for these high-tech systems. Frequent power shortages cause ongoing technical failure and Nepal lacks both the skilled expertise required for continuous maintenance and repairs, as well as spare parts, which often need to be imported.

Such problems are prevalent throughout the developing world, where the ability to maintain sophisticated wastewater treatment plants is lacking. As a result, urban environments are highly polluted, public health is jeopardized, and economic growth and development prospects are hindered.

In response to this sanitation crisis in Nepal, the objective of this research was to investigate decentralized sanitation and wastewater management, which has already been piloted in a handful of communities around the country. The communitycentred approach is considered to be both a cost-effective and sustainable solution to the challenges of urban environmental sanitation. As such, this research intends to substantiate these claims, while providing a knowledge base for decision-makers regarding the further implementation of these approaches. It is therefore important to liberate the driving factors behind initial implementation and long-term sustainability, as well as the various barriers hindering success and widespread scaling-up of this approach.

\section{Research foundations}

Decentralized wastewater treatment systems (DEWATS ) and management were chosen for this research, assuming the suitability of this approach within emerging urban contexts. DEWATS encapsulate a simple, proven, affordable and low-maintenance approach for the treatment of organic wastewater, promoted by a worldwide network of sanitation organizations and experts (Gutterer et al., 2009). In recent decades, alternative concepts for sustainable urban sanitation have been adopted and implemented throughout Asia. This paper focuses on DEWATS experiences from Asia, as DEWATS in African and Latin American countries are still in their infancy and there are few studies outside of Asia available for comparison. 
In countries like Indonesia, Vietnam or India, where more than 80 per cent of the urban population is not connected to centralized sewerage and wastewater treatment systems, DEWATS are seen as an attractive alternative (Eales et al., 2013). Programmes in Indonesia and India supported by the Bremen Overseas Research and Development Association (BORDA) have promoted DEWATS since 2002 and proven that it can be a more flexible and modular alternative to centralized sewered systems, able to meet national effluent standards with lower capital and operational costs (Gutterer et al., 2009).

Since 2009 the Indonesian Government has been expanding the implementation of DEWATS , aiming to reach over 6 million people between 2010 and 2014 - about 5 per cent of the urban population (Eales et al., 2013). Currently, over 1,500 DEWATS are in operation in India and Indonesia alone (ibid.). DEWATS are operated with a variety of management options including community-managed, utilitymanaged or co-managed systems that divide responsibilities between day-to-day O\&M (by the community) and de-sludging/major maintenance and repairs (by the local authority or the utility). Seeking to reduce transaction costs, current DEWATS innovations include validation of co-management partnerships and the standardization of technical options through prefabrication of wastewater treatment units.

In Nepal, DEWATS were introduced towards the end of the 1990s, in the form of constructed wetlands (CW) with sedimentation tanks or anaerobic baffle reactors (ABR) (ENPHO, 2010b). Interest in DEWATS and technologies has continued to grow, with more than 13 DEWATS constructed across Nepal, and a handful currently under construction (WaterAid Nepal, 2008). There is significant potential for scaling up the application of these alternative technologies, as existing examples are generally well-accepted with high levels of user satisfaction.

\section{Methods}

Between September 2012 and February 2013, field-based 'action research' was undertaken in Nepal, with support from GFA Consulting Group's Municipal Support Team (MST) as well as the Swiss Federal Institute of Aquatic Science and Technology (EAWA G) Department of Water and Sanitation in Developing Countries (SANDEC).

In order to assess the suitability of DEWATS for Nepal's emerging urban regions and proceed with the further application of such practices, this research sought to evaluate and compare existing models and their respective attributes, particularly in terms of planning, funding, implementation, and O\&M.

The above-mentioned criteria were incorporated into a comparative assessment of three case-studies - Sunga, Srikhandapur, and Nala - constructed in 2006, 2008, and 2012, respectively.

These examples were selected according to the following characteristics:

- urban or peri-urban nature;

- consisting of between 200 and 400 households, which is considered to be a

- manageable scale for sustainable DEWATS;

- representing various types of technical configuration and management;

- representing various stages between initial implementation and ongoing O\&M. 
This research employed empirical methods for both qualitative and quantitative data collection and assessment, and the findings were obtained through the following instruments: user interviews, site visits, and expert interviews.

\section{User interviews}

Interviews with nine users were conducted in Nepal during site visits to the case study communities of Sunga, Srikhandapur, and Nala. Interviews were undertaken with the respective DEWATS users' committees, caretakers and households connected to biogas, where applicable (see Table 1).

Table 1 User interviewee categories

\begin{tabular}{lccc}
\hline & Sunga & Srikhandapur & Nala \\
\hline DEWATS users' committee member & 1 & 1 & 1 \\
Paid Caretaker & 1 & 1 & $1^{*}$ \\
Users connected to biogas & $0 * *$ & 3 & $0^{* *}$
\end{tabular}

* As the DEWATS in Nala was not yet operational at the time of writing, no caretaker from this location could be interviewed. Instead, an additional interview was conducted with the DEWATS engineer who is responsible for training the future caretaker.

** Three additional interviews were conducted in Srikhandapur, with household and local school users connected to the biogas system. These interviews were to assess the level of user-satisfaction with the DEWATS biogas component.

Interviews were administered through both structured questionnaires and semistructured discussions, where respondents could respond freely to the subject. The intention of these interviews was to assess the level of user involvement in the planning process and 'ownership' of the sanitation intervention, as well the extent of the associated benefits and user satisfaction levels.

\section{Site visits}

Site visits to six exemplary models of community-scale DEWATS (incorporating ABR, $\mathrm{CW}$, and/or biogas) were undertaken at several locations within the Kathmandu Valley, as well as two locations in Nagpur, India. The DEWATS engineers or implementation officers often came on these visits, which were necessary to assess the technical performance beyond what was available in secondary literature.

\section{Expert interviews}

Interviews were performed with 12 sanitation experts in Nepal, to obtain their perspectives on environmental sanitation, ecological sanitation, and DEWATS. The experts were asked why they thought these alternative - and commonly heralded concepts of sanitation hadn't naturally taken off across other parts of the country. The interviews helped to ascertain the main factors hindering the scaling up of these sanitation approaches. 
Interviews were conducted with experts from relevant donor agencies and local non-governmental organizations as well as government representatives and other local stakeholders. Meetings were administered as semi-structured interviews, with open-ended questions. Respondents were interviewed in English and the sessions digitally recorded, wherever consent was given.

\section{Introduction to case studies}

\section{Sunga}

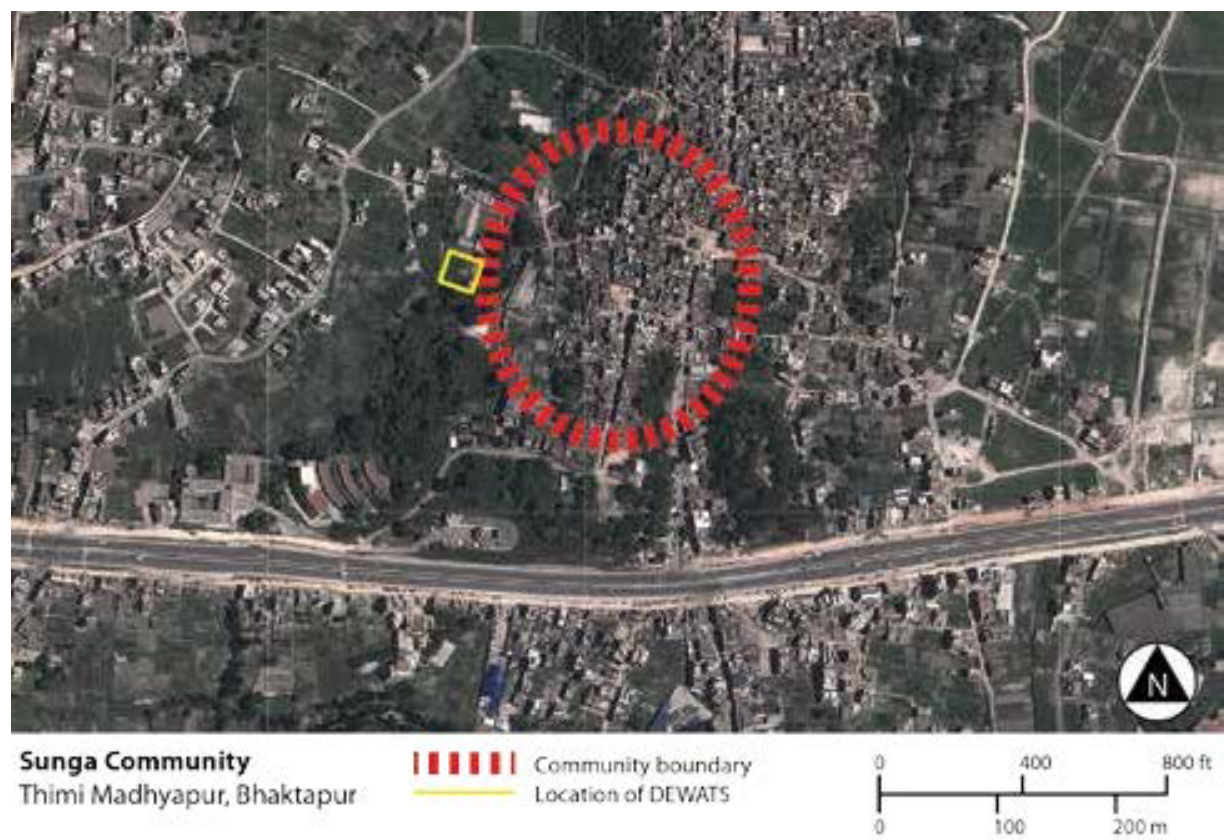

Figure 1 Satellite photo of Thimi Madhyapur showing Sunga community Source: adapted from Google Maps

The community of Sunga represents a low-income and socially marginalized urban cluster within the Madhyapur Thimi Municipality of Bhaktapur District, approximately 10 kilometres from Kathmandu (see Figure 1). Between 2005 and 2006, the community-based wastewater treatment project was implemented; the first of its kind in Nepal (WaterAid Nepal, 2008). Through the use of CW (see Figure 2 ), this DEWATS was designed to treat the sewage of 200 households, which was previously discharged directly into the neighbouring Siddhikali River (ENPHO, 2010a). At the same time, this project intended to set a precedent for larger-scale wastewater treatment systems in other areas of Nepal (WaterAid Nepal, 2008): 'to demonstrate appropriate technology for decentralised wastewater management at the community level'. 


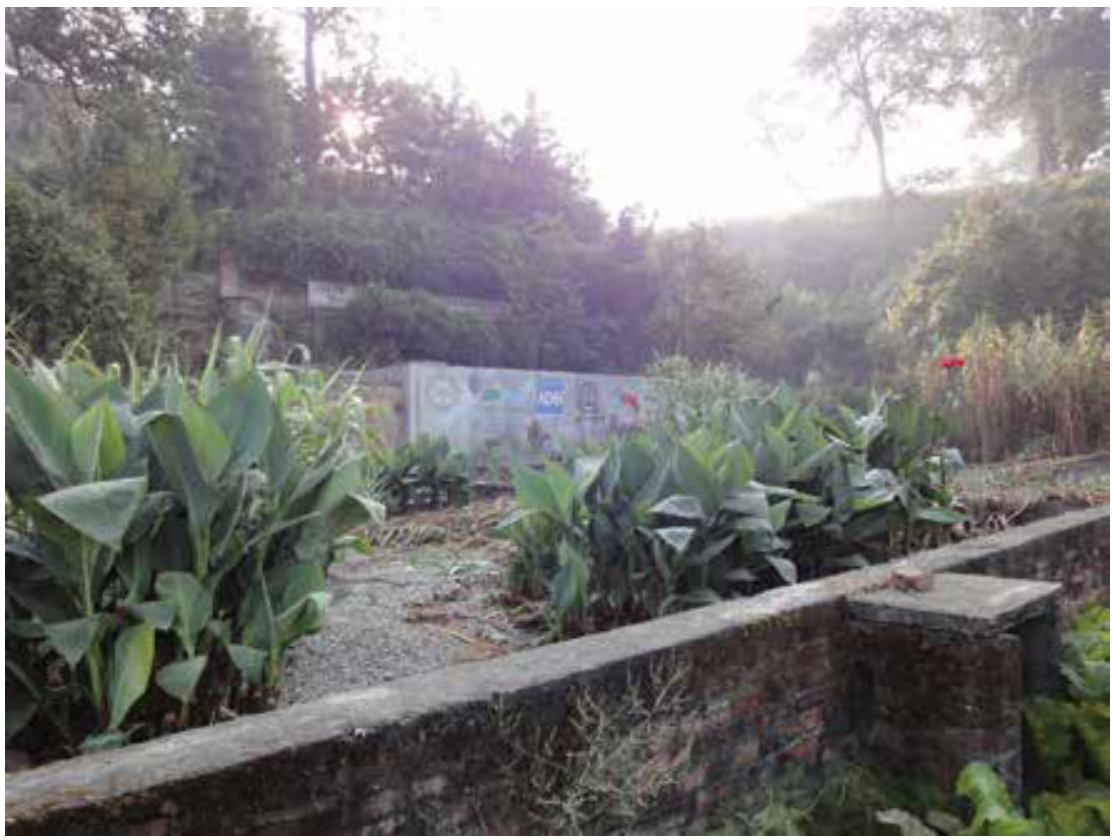

Figure 2 Photo of the Sunga DEWATS

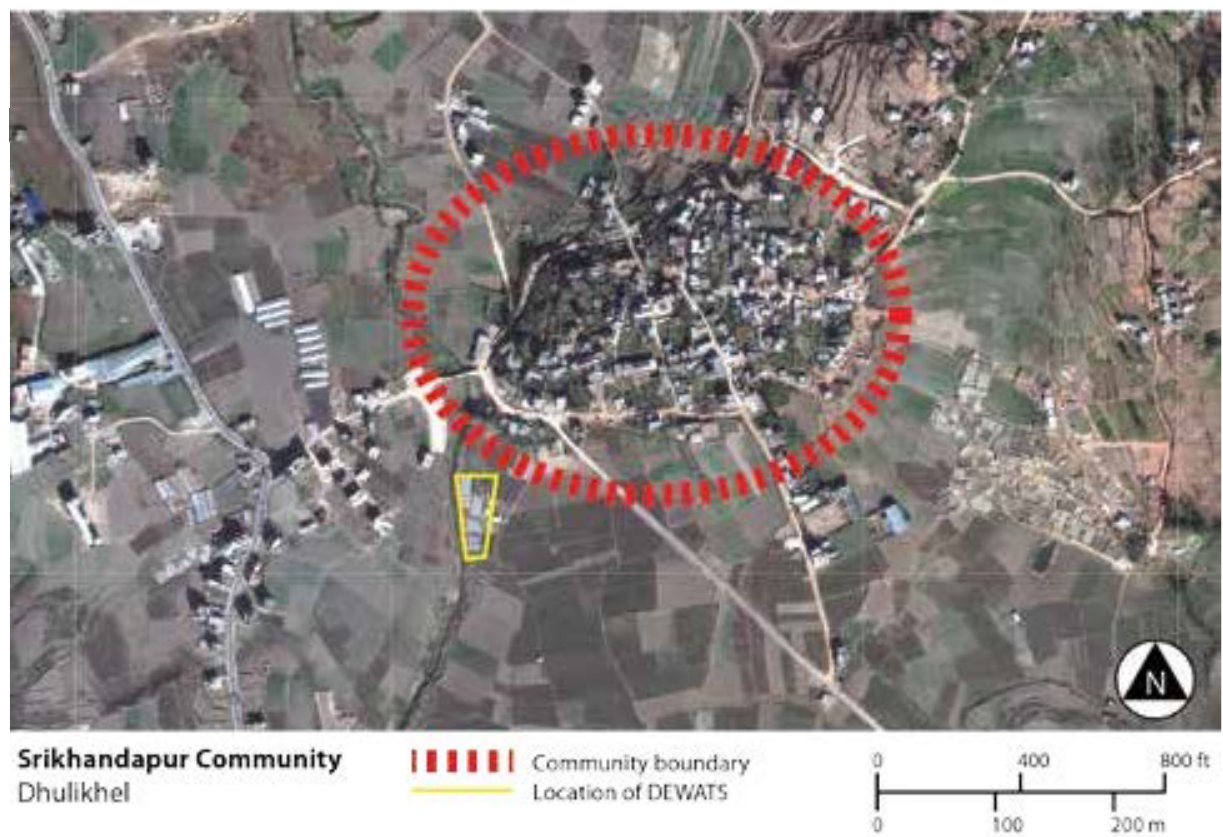

Figure 3 Satellite photo of Dhulikhel showing Srikhandapur Community Source: adapted from Google Maps 
After the construction and initial success of Sunga DEWATS, this model was replicated in the peri-urban settlement of Srikhandapur, located 32 kilometres from Kathmandu in Dhulikhel Municipality (see Figure 3). The community-based wastewater treatment plant (WWTP) using horizontal CW (see Figure 4) was constructed in 2008 and designed to serve approximately 200 households (ENPHO, 2010c). Similarly to Sunga, the purpose of the Srikhandapur project was to improve the condition of environmental sanitation by treating the wastewater, which was previously being discharged into the nearby river. In addition to wastewater treatment, this system includes the production of biogas for use by local residents as an alternative energy source for cooking. The intention of combining these technologies was to demonstrate the economic feasibility of biogas to finance ongoing O\&M of the DEWATS .

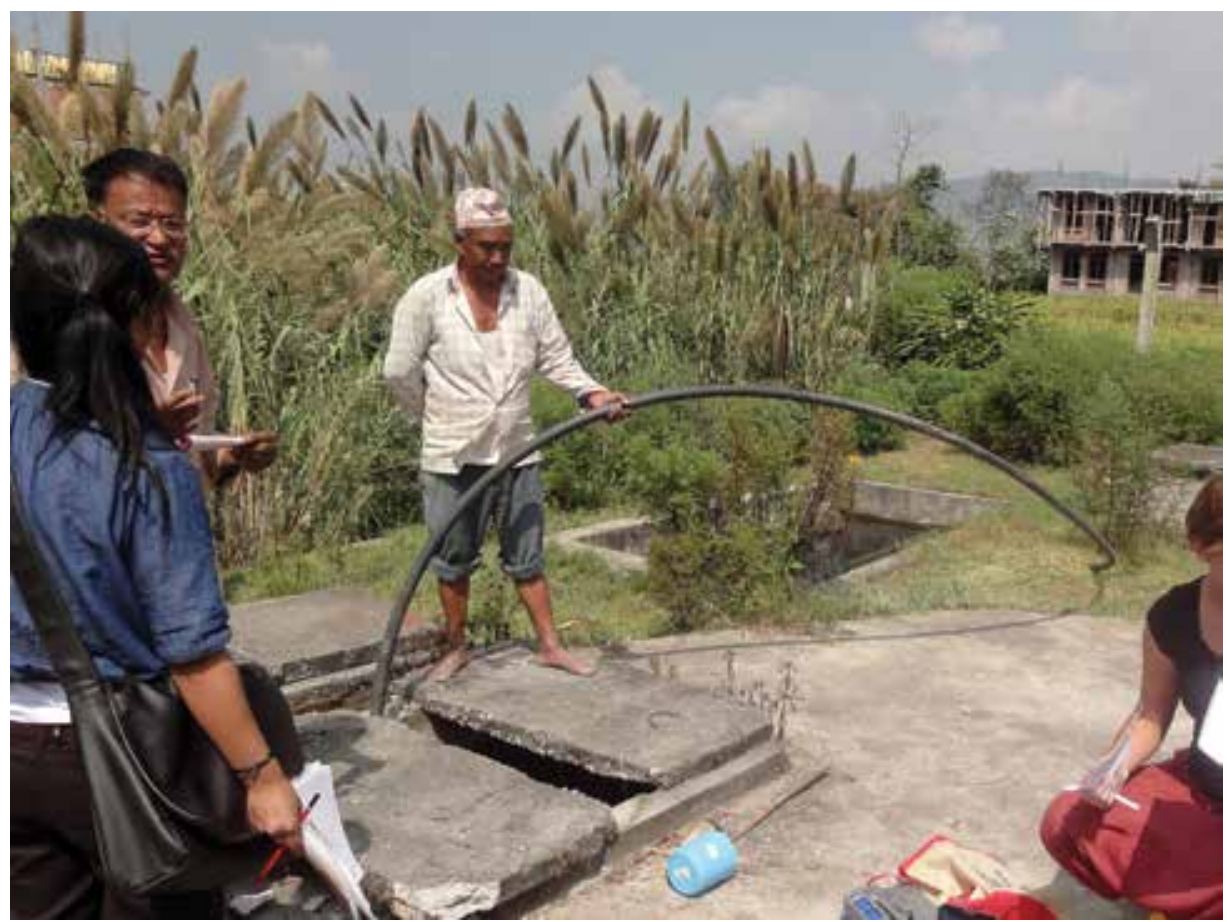

Figure 4 Photo of the DEWATS at Srikhandapur, with on-site caretaker 


\section{Nala}

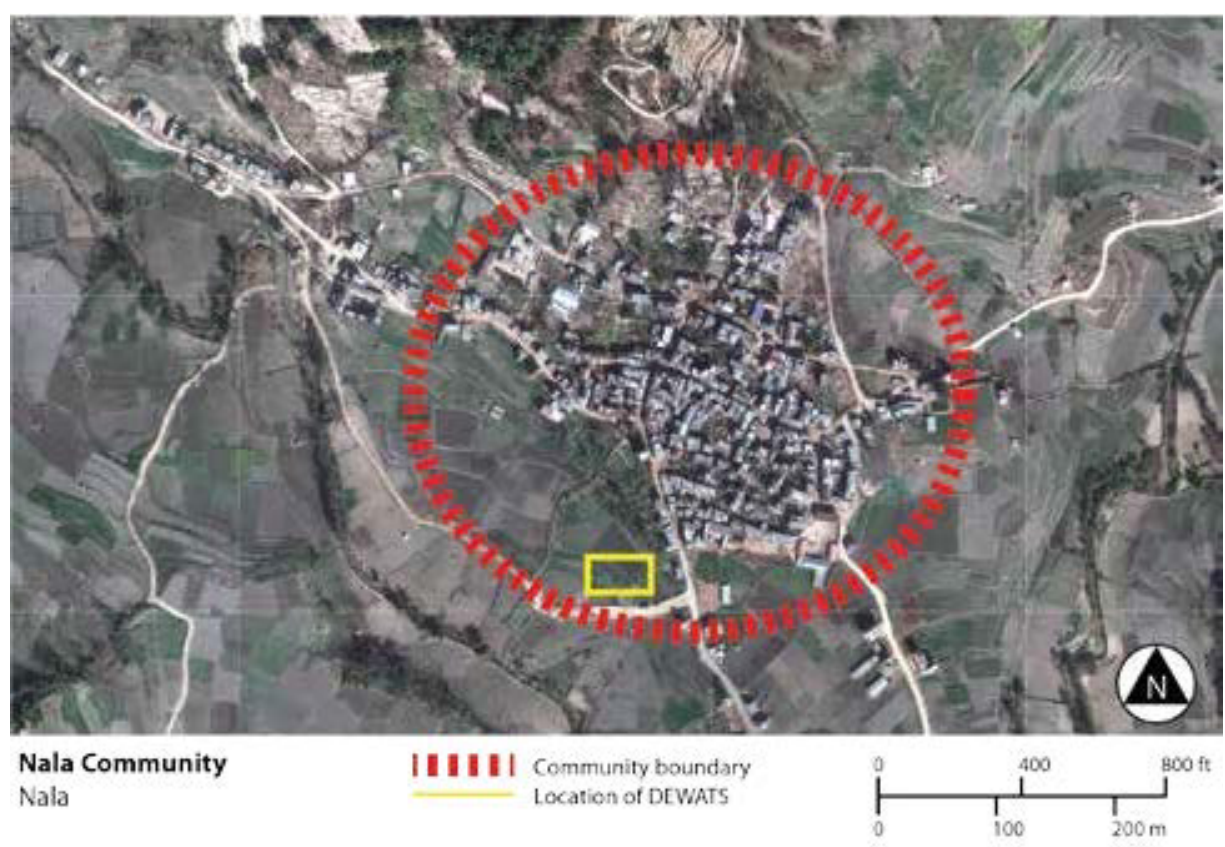

Figure 5 Satellite photo of Nala

Source: adapted from Google Maps

Nala Bajar is a peri-urban settlement located in the Kavre District approximately 30 kilometres from Kathmandu (see Figure 5). Designed to serve 294 households, Nala has been operational since December 2012 and therefore presents the most recent example of community-led sanitation improvement in Nepal. This project was selected as a case study as it addresses the problems experienced in the previous DEWATS examples of Sunga and Srikhandapur, and adopts alternative solutions accordingly.

Nala is one of the initial locations where the community-led urban environmental sanitation (CLUES) planning process has been field-tested, with the intention to validate the planning approach, identify challenges, and improve the process. CLUES is a set of planning guidelines to assist disenfranchised urban and peri-urban communities to plan and achieve improved environmental sanitation and associated infrastructure (Lüthi et al., 2011). Nala has adopted the treatment methods of an ABR combined with a horizontal flow, gravel-bed filter (see Figure 6). Nala also provides a precedent for simplified sewers, and is the first of its kind to serve an entire peri-urban settlement in Nepal. 


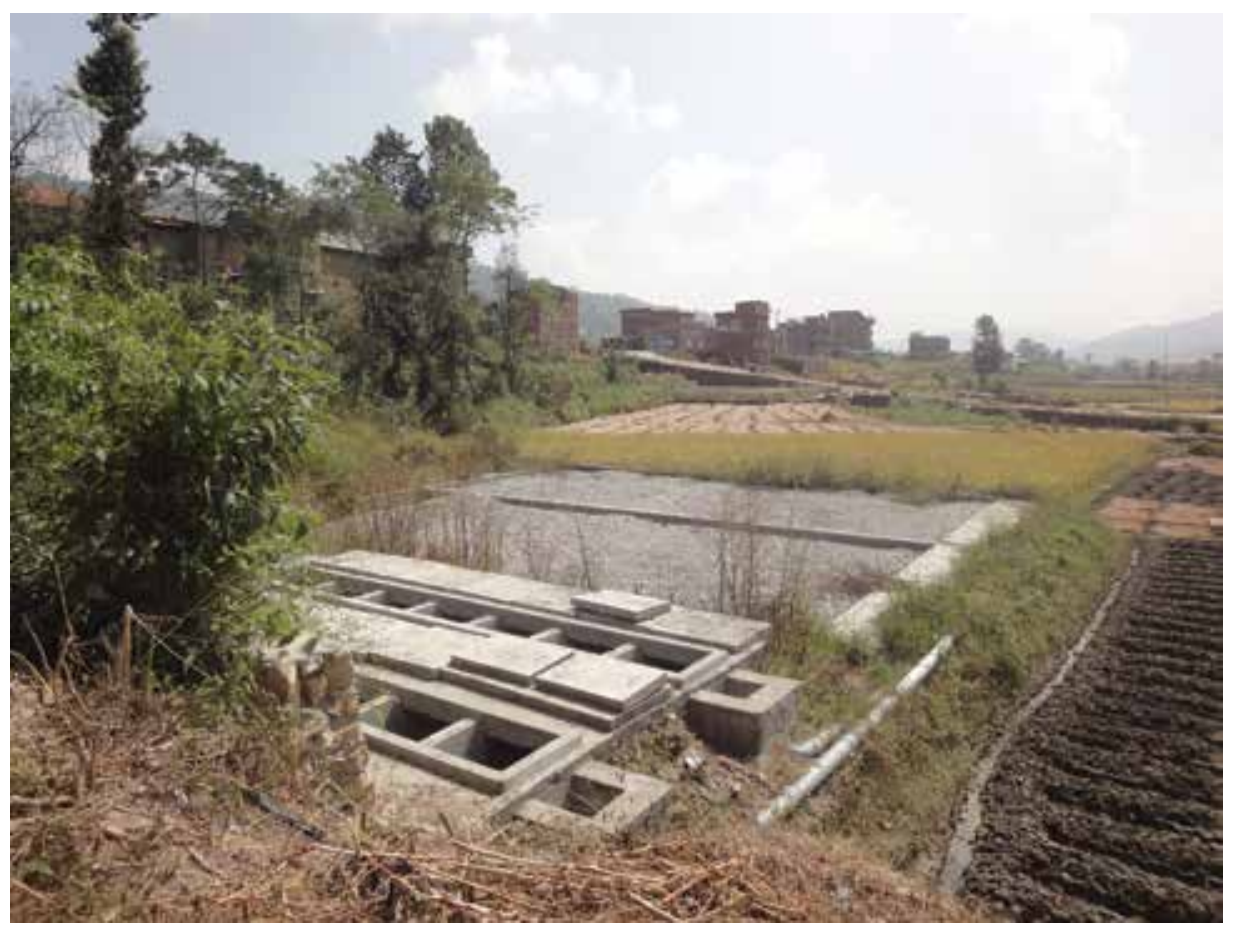

Figure 6 Photo of the DEWATS in Nala

\section{Comparative analysis and overviews from case studies}

This section presents a comparative analysis of the three above-mentioned case studies, in order to assess the planning and implementation processes, long-term management strategies, institutional capacity and stakeholder engagement, and technical aspects. It should be noted that the finer technical aspects of the DEWATS - such as the relevance of technical choices, quality of construction, quality of maintenance, and finally performance of systems - have not been included within the scope of this discussion, with assessment parameters focused more on the planning and managerial aspects. The presentation of results will be complemented by a discussion of general overviews, including the opportunities and challenges associated with scaling-up.

\section{Planning process and implementation (including costs)}

Sunga, Srikhandapur, and Nala are all considered to be examples of community-based sanitation; however the planning and implementation processes employed in the first two differ considerably from the latter. Table 2 provides a comparative overview of these processes. In the first two projects (Sunga and Srikhandapur), implementation was top-down with limited participatory planning. Although communities 
in both locations were initially receptive to a sanitation intervention - with high attendance levels at community meetings in Sunga, and financial contributions from the Srikhandapur community towards construction - their actual input into the decision-making processes, general awareness surrounding sanitation options, and retrospective sense of ownership of the system appears to be minimal. This could be the reason for the subsequent difficulties with long-term maintenance.

While the communities were evidently present throughout the planning and implementation processes, their participation appears to have been more tokenistic; allowing them to 'hear' and 'be heard' through informing and consultation, but denying them any assurance that their views would be observed (Arnstein, 1969).

Both models in Sunga and Srikhandapur were piloted through UN-HABITAT Nepal, as demonstration projects for community-based wastewater treatment, and as such they achieved their intention of up-scaling a relatively new technology and concept of decentralization to the community scale. While both UN-HABITAT pilots associate the term 'community-based' sanitation with the notion of decentralizing wastewater management, the role of the community in achieving optimal sanitation solutions and ensuring long-term management appears to have been overlooked.

Nala, on the other hand, addresses the shortfalls of the previous examples and presents a significant deviation from top-down planning. In this case, communityscale decentralized wastewater management is achieved by placing the community at the centre of the process, hence the term 'community-led' planning. This is a more inclusive form of citizen participation, where the community hold equal weight within the partnership and can negotiate as well as engage in decisions that directly affect them (Arnstein, 1969).

A comparison of the total expenditure for planning and implementation reveals significant variation between NPR2.1 $\mathrm{m}$ (Sunga), NPR7.4 m (Srikhandapur), and NPR12.6 $\mathrm{m}$ (Nala) (NPR1 $\mathrm{m} \approx$ US $\$ 10,400$ ). While positive inflation between the respective dates of construction $(2006,2008$, and 2012) is only one small factor of the cost disparity, the main reason for higher costs in Srikhandapur compared to Sunga - which were both designed to serve 200 households - was the inclusion of biogas within the service option. The extra capital was provided by external donors with the intention that biogas would help finance community management and O\&M, although the biogas production and sale could never pay back initial construction costs. In this sense, such a system would be unaffordable for communities without some form of external financial assistance.

In Nala, there are a number of reasons for the higher implementation costs. Firstly, the system is designed for 294 households, requiring almost 50 per cent more capacity than the previous two examples designed for 200 households. However, due to economies of scale this is not the main cause of the greater expenditure, and in fact the per capita expenditure in Nala was just NPR5,590 (cost calculations from Sherpa et al., 2012). Approximately 10 per cent of the total expenditure went on the 12-month planning process, which included thorough community mobilization efforts.

While such a planning process might seem extraneous, the long-term financial, environmental, and social benefits are expected to outweigh - and therefore validate 
Table 2 Comparing planning and implementation processes

\begin{tabular}{|c|c|c|c|c|}
\hline & & Sunga & Srikhandapur & Nala \\
\hline \multirow{10}{*}{ 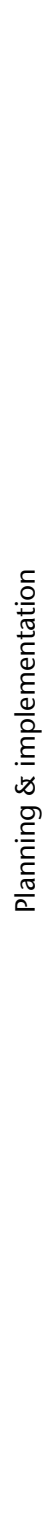 } & Type of Project & $\begin{array}{l}\text { Demonstration Project } \\
\text { for Community-based } \\
\text { Wastewater treatment }\end{array}$ & $\begin{array}{l}\text { Demonstration Project } \\
\text { for Community-based } \\
\text { Wastewater treatment } \\
+ \text { Biogas }\end{array}$ & $\begin{array}{l}\text { Pilot Project for } \\
\text { Community-led Urban } \\
\text { Environmental } \\
\text { Sanitation (CLUES) }\end{array}$ \\
\hline & $\begin{array}{l}\text { Planning / } \\
\text { Implementation } \\
\text { period }\end{array}$ & 2005-2006 & 2008 & 2009-2012 \\
\hline & $\begin{array}{l}\text { Planning / } \\
\text { Implementation } \\
\text { Costs (NPR) }\end{array}$ & Total $=2.1$ million & Total $=7.4$ million & $\begin{array}{l}\text { Total }=12.6 \text { million } \\
\text { (US } \$ 145,771)\end{array}$ \\
\hline & & & & $\begin{array}{l}\text { - } 1.2 \text { million for } \\
\text { planning (US } \$ 13,500 \text { ) } \\
\text { - } 11.4 \text { million for } \\
\text { implementation } \\
\text { (US } \$ 132,271 \text { ) }\end{array}$ \\
\hline & $\begin{array}{l}\text { Number of } \\
\text { Households }\end{array}$ & 200 & 200 & 294 \\
\hline & $\begin{array}{l}\text { Costs per } \\
\text { Household }\end{array}$ & $\begin{array}{l}\text { NPR 10,500 } \\
(\times 200 \mathrm{HH})\end{array}$ & $\begin{array}{l}\text { NPR 37,000 } \\
(\times 200 \mathrm{HH})\end{array}$ & $\begin{array}{l}\text { NPR 43,000 } \\
(\times 294 \mathrm{HH})\end{array}$ \\
\hline & & & & $\begin{array}{l}\text { - NPR 4,000 for } \\
\text { planning } \\
\text { (US } \$ 46) \\
\text { - NPR 39,000 for } \\
\text { implementation } \\
\text { (US } \$ 450)\end{array}$ \\
\hline & $\begin{array}{l}\text { Funding } \\
\text { Agencies }\end{array}$ & $\begin{array}{l}\text { ADB, UN-HABITAT, } \\
\text { WaterAid Nepal }\end{array}$ & $\begin{array}{l}\text { UN-HABITAT, } \\
\text { Dhulikhel } \\
\text { Municipality, } \\
\text { Srikhandapur } \\
\text { Community }\end{array}$ & $\begin{array}{l}\text { UN-HABITAT, } \\
\text { EAWAG-SA NDEC, } \\
\text { WaterAid Nepal, Nala } \\
\text { Community, Nala VDC }\end{array}$ \\
\hline & $\begin{array}{l}\text { Community } \\
\text { Contribution }\end{array}$ & $\begin{array}{l}\text { Land donated by } \\
\text { Municipality }\end{array}$ & $\begin{array}{l}\text { Land donated by } \\
\text { Municipality }\end{array}$ & $\begin{array}{l}\text { Partial financial } \\
\text { support provided by } \\
\text { Nala VDC for land } \\
\text { acquisition } \\
\text { Community } \\
\text { contributed 33\% } \\
\text { of planning and } \\
\text { implementation costs }\end{array}$ \\
\hline & $\begin{array}{l}\text { Supporting } \\
\text { Organisation }\end{array}$ & ENPHO & $\begin{array}{l}\text { ENPHO, BSP Nepal } \\
\text { CIUD - NGO }\end{array}$ & \\
\hline
\end{tabular}

CIUD: Centre for Integrated Urban Development; HH: Households; NPR: Nepalese Rupees*;

VDC: Village Development Committee.

*At the time of writing, the value of the Nepalese Rupee was as follows:

US $\$ 1=$ NPR $87.35 /$ NPR $100=$ US $\$ 1.15$

Sources: ENPHO, 2010a; ENPHO, 2010c; Sherpa et al., 2012. 
- the initial time and monetary investment. The lack of such an intensive participation process in the other two communities resulted in lower initial implementation costs, but higher O\&M costs, as well as subsequent difficulties with long-term financing.

These planning processes in Nala also led to a considerably higher community contribution of 33 per cent towards overall planning and implementation costs. Although the total expenditure in Nala was greater than in Sunga or Srikhandapur, due to the high engagement and contribution from the community, per capita costs are considered to be remarkably low for a sanitation intervention of this kind. NPR5,590 (\$58) per capita equates to less than half of the capital costs cited in sector literature for similar networked sanitation systems.

\section{Technical aspects}

All three sanitation systems demonstrate various DEWATS configurations (see Table 3). For primary treatment, the Sunga plant employs an ABR and settler, Srikhandapur has two bio-digesters, and Nala has two ABRs. For secondary treatment, all three have adopted CWs in the form of gravel beds or reed-bed treatment systems. One main distinction in Nala is the separation of black water and other waste streams. Also the mode of conveyance in Nala is different, as it uses a simplified sewerage system while the other two systems employ a conventional system with combined wastewater streams.

Despite their varying technical configurations and conveyance methods, the consistent selection of DEWATS makes sense within the context of Nepal, for the following reasons:

- low-tech solutions = low-maintenance;

- low capital investment required for installation;

- minimal ongoing costs after initial installation;

- reliable option for localized treatment of domestic wastewater.

Another technical variation is the biogas component found in Sunga and Srikhandapur DEWATS, although only the latter example is currently functional, and with questionable success. Biogas is a welcome alternative to conventional gas in a world of increasing gas prices and scarcity. However, as an addition to WWTPs it is still in the early stages of development in Nepal, and as yet, no pilot projects have yielded results convincing enough to warrant large-scale adoption of this technological option. The main reasons for poor performance are technical shortcomings in the original design and construction of biogas components, combined with insufficient or inconsistent O\&M. According to the engineer of Nala's WWTP, biogas was originally included as part of the sanitation system proposal but later abandoned due to the poor performance of other biogas integrated WWTPs in Nepal. 
Table 3 Comparing technical aspects

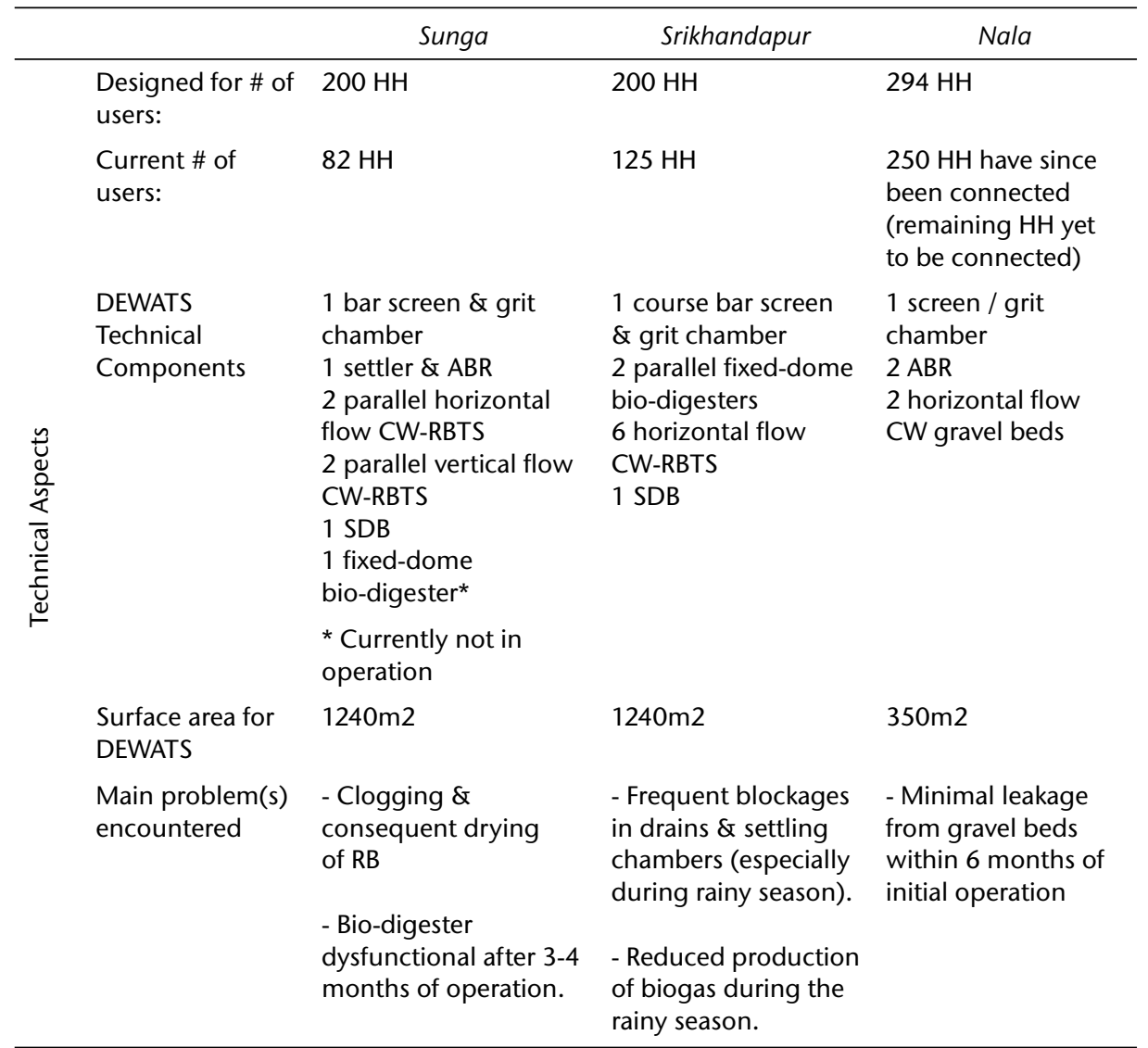

ABR: Anaerobic baffle reactor; $\mathrm{CW}$ : Constructed wetland; $\mathrm{HH}$ : Households; RBTS : Reed-bed treatment system; RB: Reed-bed; SDB: Sludge drying bed. Sources: ENPHO, 2010a; ENPHO, 2010c. 


\section{Long-term management/operation and maintenance}

Table 4 Comparing long-term management strategies

\begin{tabular}{|c|c|c|c|c|}
\hline & & Sunga & Srikhandapur & Nala \\
\hline \multirow{6}{*}{ 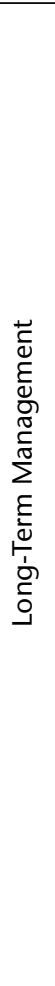 } & $\begin{array}{l}\text { O\&M } \\
\text { Management } \\
\text { Agency }\end{array}$ & $\begin{array}{l}\text { Sunga Wastewater } \\
\text { Treatment Plant } \\
\text { Management } \\
\text { Committee }\end{array}$ & $\begin{array}{l}\text { Srikhandapur Sewage } \\
\text { Treatment User } \\
\text { Committee }\end{array}$ & $\begin{array}{l}\text { Nala Water Supply } \\
\text { and Sanitation Users' } \\
\text { Committee }\end{array}$ \\
\hline & $\begin{array}{l}\text { O\&M Costs } \\
\text { (NPR) }\end{array}$ & $\begin{array}{l}50,000 / \text { year* } \\
(36,000 \text { for } \\
\text { caretaker's salary }+ \\
\text { max } 14,000 \text { annual } \\
\text { allowance for } \\
\text { maintenance })\end{array}$ & $\begin{array}{l}55,000 / \text { year } \\
(36,000 \text { for } \\
\text { caretaker's salary }+ \\
\text { additional } 19,000 \text { for } \\
\text { maintenance })\end{array}$ & $\begin{array}{l}\text { Approx. } \\
165,000 / \text { year* } \\
(104,000 \text { for caretaker's } \\
\text { salary }+10,000 \text { for ABR } \\
\text { desludging + }\end{array}$ \\
\hline & & $\begin{array}{l}\text { *This amount is } \\
\text { currently not sufficient } \\
\text { to cover all associated } \\
\text { costs }\end{array}$ & $\begin{array}{l}\text { * The caretaker is not } \\
\text { receiving this amount }\end{array}$ & $\begin{array}{l}36,000 \text { for WSUC office } \\
\text { rent }+15,000 \text { misc.) } \\
\text { * Exact costs will vary } \\
\text { with time }\end{array}$ \\
\hline & $\begin{array}{l}\text { O\&M } \\
\text { Financing } \\
\text { (User fees) }\end{array}$ & Municipality & $\begin{array}{l}\text { User service fees*: } \\
\text { Biogas users }(5 \mathrm{HH}) \\
\text { contribute NPR } 500 / \\
\text { month }=25,000 / \text { year }\end{array}$ & $\begin{array}{l}\text { User service fees per } \\
\text { HH using the sewer- } \\
\text { based system: } \\
\text { NPR 500/year }\end{array}$ \\
\hline & & & $\begin{array}{l}\text { Users connected to } \\
\text { sewage system pay } \\
200 / \text { year }=30,000 / \\
\text { year }\end{array}$ & $\begin{array}{l}\text { *With a reserve fund of } \\
\text { approx. } \\
\text { NPR } 600,000 \text { for } \\
\text { maintenance, which } \\
\text { comes from the } \\
\text { revolving fund }\end{array}$ \\
\hline & & & $\begin{array}{l}\text { * Payment of service } \\
\text { fees is not enforced }\end{array}$ & \\
\hline
\end{tabular}

HH: Households; NPR: Nepalese Rupees; O\&M: Operation \& Maintenance; WSUC: Water Supply/Sanitation Users' Committee.

Sources: Sherpa et al., 2012.

Table 4 compares the various management and financing strategies surrounding long-term O\&M of the three DEWATS . In terms of functional longevity of DEWATS and sustained O\&M, the case studies have shown that through the implementation phases, the attitude towards DEWATS needs to be addressed as a 'low maintenance' solution, as opposed to a 'no maintenance' solution. The inherent merits of DEWATS lie within its low maintenance requirements, but even low-maintenance systems require mechanisms for financial stability to ensure long-term management and O\&M.

In many cases of DEWATS in Nepal, this is often not addressed until after the system is constructed, if at all. In these scenarios, users are unaware of the importance of O\&M and therefore reluctant to pay for such services. Even in cases where the 
community was actively engaged in improving their sanitation conditions, problems always arise after the handover process, when external support and financing stops.

Where the problems of poor environmental sanitation are severe and/or unavoidable, residents are initially highly motivated to find solutions and even express willingness to pay. However, once the sanitation problem is solved and is no longer an immediate, visible inconvenience, there is a reluctance to pay for its ongoing service. This is a recurring scenario with community-scale DEWATS in Nepal.

Developing a participatory O\&M plan - such as in Nala - can be the first step for combatting the aforementioned O\&M challenges. The strategy helps users visualize the whole sanitation system, identify immediate problems, and find appropriate solutions at the local level. Heightened awareness of improved environmental sanitation and its importance means the users' willingness to pay is increased. Particularly in emerging towns and urban areas, where people are both able and willing to pay for such a service and for the long-term sustenance of the system, the inclusion of a user service fee is a must.

In Sunga, the municipality is now considering incorporating a user-fee system, to help finance technical issues and $O \& M$ requirements. However, because there were no initial community mobilization and awareness programmes, and the community always assumed that someone else would be responsible for financing O\&M, objection to user fees is expected. This situation reinforces the value of community involvement from the outset in increasing awareness and acceptance surrounding user service fees.

\section{Institutional capacity and stakeholder engagement}

User committees were established in all three locations to assist within the implementation phases, while taking on the management responsibilities after operation. In the case of Sunga, however, the original Wastewater Treatment Plant Management Committee formed in 2005 has since dissolved, as the local Municipality took over the majority of responsibility for the WWTP. However, the previous president of this user committee has said that if the existence of the DEWATS is to be sustained, there is an urgent need to raise awareness among the users, reform the committee, and introduce a user-pay system.

In Srikhandapur, while the Sewage Treatment User Committee is still active and the president is a proud spokesperson for promotion of the WWTP within the community, institutional capacity is somewhat limited. Due to a lack of support from the Dhulikhel Municipality, the users' committee has limited authority to enforce pre-established regulations, such as regular payment of user service fees. As a result there are insufficient funds for $\mathrm{O} \& \mathrm{M}$, and the future of the on-site caretaker is uncertain. Nala intends to address problems such as these before they arise, through the establishment of the Nala Water Supply and Sanitation Users' Committee. This committee is a legal entity registered with the local authorities and has taken full ownership of the project. Thus, it is responsible for ensuring long-term O\&M upon operation of the sanitation system. 
The outcomes from the approach adopted in Nala are expected to highlight the importance of developing institutional capacity and stakeholder engagement for ensuring O\&M sustainability. A strengthened sense of responsibility and ownership can contribute to long-term management, which can be achieved through stakeholder participation in the process from initial inception right through to construction and beyond.

For post-construction sustainability of DEWATS, the concept of 'co-management' needs to be addressed as part of the development of institutional capacity, and not just 'community management' as there will always be limits to community expertise and awareness, even in situations where social cohesion is strong and awareness surrounding water, sanitation, and hygiene is high. Co-management implies a cooperative partnership between the community and local municipality or private sector. This kind of community responsibility is absent in the ongoing operation of Sunga, while municipal involvement is absent in the case of Srikhandapur.

Nala has addressed this issue by empowering the community, not only through the establishment of a users' committee, but by strengthening the community's financial capacities with a community-managed revolving funds scheme and local monitoring body: Centre for Integrated Urban Development. All stakeholders are expected to benefit from the arrangement, attributed to a solid partnership, and contributing to sustainable O\&M of the DEWATS.

The CLUES project in Nala can be compared to similar programmes run by the Consortium for DEWATS Dissemination (CDD) in India, or BORDA. Throughout these programmes, it is common to find DEWATS have performed poorly in areas where communities were not involved from the outset.

The main difference between these approaches, however, relates to the amount and level of community participation, particularly surrounding technology choices. Where CDD and BORDA focus their efforts towards technical solutions including ABRs, CWs, and sometimes bio-digesters, CLUES planning is technology neutral. In Nala, three different technical options (from simple, on-site, urine diverting dry toilets to a more complex sewerage network) were considered before deciding on a DEWATS. In addition, Nala is the first example where an entire settlement was connected to the sanitation system, whereas CDD DEWATS tend to focus on serving middle-income pockets.

\section{Replicability and scaling-up}

Opportunities. Based on the success of the CLUES project in Nala, agencies like WaterAid Nepal and the Asian Development Bank (ADB) are promoting this approach in other emerging towns. There is also an ongoing partnership between EAWA G and ADB's Small Towns Water Supply and Sanitation Project (STWSS), which could see further piloting of the CLUES planning approach in future.

Despite the potential of DEWATS as an appropriate and promising technological sanitation solution for Nepal - environmentally, socially, and economically - there are still significant internal and external challenges for promoting its widespread adoption. 
Internal challenges. Since Sunga introduced the first community-based WWTP in Nepal, DEWATS have been demonstrated in a handful of different locations. However, these pilot projects have not yet been adopted on a larger scale due to the lack of perspective beyond conventional systems and a general tendency towards centralized systems. This opinion was reiterated by the director of ADB's STWSS Project, Ramdeep Sah:

One of the biggest obstacles thus far to replicating DEWATS may be lack of vision ... Nevertheless, the goal is neither wholly centralised nor decentralised wastewater treatment ... We have to go the middle route ... With a combination of centralised treatment in the country's most densely populated areas and DEWATS for the emerging towns, peri-urban areas, communities, institutions and private companies (IRIN 2012: para 24, $26 \& 27$ ).

DEWATS , therefore, cannot be considered as one-off, isolated solutions, but as elements to be implemented within a greater, citywide sanitation plan. In order for the ongoing O\&M costs to be affordable and sustainable, the number of DEWATS operating within close proximity needs to be increased. In such cases, it would then be possible for one full-time caretaker to manage four to five DEWATS, which would significantly reduce the O\&M costs.

Also, the limited economic capacity of communities in Nepal means capital investment is challenging in urban areas. Land in dense urban areas is a valuable commodity, difficult and costly to obtain, and municipalities or users are required to donate it, along with skilled manpower for construction. Depending on the size of the project, the management of sludge must also be incorporated into the initial technical solution and O\&M plan.

However, despite the moderate capital investment and recurrent service fees associated with DEWATS, the case of Nala has shown that even low-income communities are capable - and willing - to contribute financially towards sanitation improvement, once the benefits are effectively portrayed from the outset.

External challenges. Beyond social and technical questions at the project level itself, major obstacles can be found in the political economy and structures of Nepal with institutions and partners that are not yet ready to promote the approach. Currently, a major challenge is the lack of policies legitimizing DEWATS as valid sanitation options:

Firstly, at the government level, the urban sanitation issue has not received much priority, as the focus so far has been on rural sanitation. Once the importance of urban sanitation is realized, the potential application of DEWATS is expected to increase. In the meantime, the main market for DEWATS is in peri-urban areas, and emerging towns.

Secondly, the unattractiveness of wastewater per se and its treatment in particular, combined with the easy availability of the 'downhill solution' in Nepal makes DEWATS a low priority for municipal investments. As decision-making competences and resources are low at the local level, municipal administrations have little choice but to ignore the need for treating urban wastewater. 
However, these local hindrances should not be generalized as the main obstacles. It is not the general lack of technical capacities, policies, and lack of funds that can be fully blamed when explaining why there are only a few WWTPs in Nepal. Technical and financial desires have significantly grown over recent years - jointly with increased capacities and access to resources - but with limitations. Though the required technical expertise for wastewater treatment is nowadays available in the country, the majority of technicians, who mainly trained abroad, prefer high-tech, 'Western' solutions. These technicians, often supported by foreign experts, tend to promote larger, centralized infrastructure rather than a number of decentralized, low-tech solutions. Moreover, there are currently only a handful of trained local experts who can actually design systems such as DEWATS.

The desire for modern, conventional approaches is also supported by the multilateral organizations; ADB's STWSS Project is an exception. Donors advising central ministries responsible for the implementation of water treatment systems still prefer selling high-tech solutions, due to their own interest in bigger investments that are assumed to have stronger impact in larger areas. This approach, however, widely ignores the implications of more cost-intensive maintenance and, at the same time, that DEWATS have significantly progressed in their technical possibilities throughout the last decade.

Nepal, as any other poor country lacking sufficient structures to steer its development independently, has little room to develop its own, adequate visions. This is, first of all, caused by its high dependence on development aid, namely for local and urban infrastructure with a 'business climate' adverse to innovation.

For example, in the ancient city of Tansen, World Bank officials withdrew their previous consent to finance a DEWATS for more than 200 households. Though the entire community was sensitized, had actively formed a committee, and was willing to support and contribute to the installation and maintenance of a DEWATS in their ward, the project was deemed too costly in maintenance. The examples given here from other cities nevertheless show a different picture and suggest that the reason is rather one of ideological bias.

Summary of decentralization challenges and opportunities. During the 1990s much progress was made in Nepal on decentralizing governments to district and village levels. The Local Self-Governance Act of 1999 paved the way to make planning and programme implementation more accountable to local people and to give urban governments the responsibility for sewerage and waste management among other tasks.

These efforts, however, have not yet been entirely successful due to the larger unsolved political backlog, as the nation is still governed by an Interim Constitution with an absence of elected representation at the local level for more than 10 years.

Notwithstanding, some issues could be addressed immediately:

- The capacity of local bodies, especially in urban areas, needs to be increased with regular training and support on technical and social subjects.

- Their responsibility to implement decentralized projects should be increased parallel to their capacities. 
- All urban bodies need to improve or update their Periodic Plans including a strategic sanitation plan (with the appropriate use of resources, monitoring, and maintenance).

- The dependence of local bodies on central institutions and national grants should be diminished by increasing their share of the national budget and by supporting their revenue generation potential, thus enabling them to provide the relatively low investment costs for DEWATS by themselves.

\section{Conclusions}

The three case studies analysed within this paper highlight the potential of DEWATS as an appropriate technical solution for urban areas in Nepal, particularly as an alternative to centralized systems, which have overwhelmingly proved to be ineffective within such contexts.

These various iterations of community-scale DEWATS provide valuable lessons for ongoing sustainability and future replication of this approach. The way forward for decentralized sanitation solutions in Nepal should incorporate the following considerations:

- The importance of community participation throughout the planning and implementation stages (and beyond). Inclusive and sustained participation from the outset, combined with an increased sense of responsibility, are considered fundamental elements for ensuring sustainability of community-led projects.

- The appropriate selection of technological configuration, combined with further technological development, is essential to minimize potential malfunction of future systems (e.g. biogas has high potential, but only where technical efficacy can be guaranteed).

- The incorporation of systematic financing mechanisms (e.g. user service fees or revolving fund schemes) is an integral part of the implementation plan, and vital for ongoing O\&M. Users must also understand and acknowledge the connection between paying a tariff and receiving civil services.

- Policy backing, government support, and institutionalization of the technology of DEWATS as a suitable option for peri-urban areas and emerging towns would increase demand.

This research found that DEWATS are more technologically and financially sustainable when implemented through the strategic CLUES planning process, which highlights the importance of O\&M and gives users a sense of ownership. In addition, CLUES incorporates the social advantages of a community-led process, such as user-centred solutions and community empowerment, with the ecological benefits of environmental sanitation and holistic consideration of all waste streams to achieve a sanitary environment.

As such, the technical 'hardware' aspects of DEWATS, combined with the planning and implementation 'software' aspects of CLUES planning, can be considered a most suitable response for urban environmental sanitation improvement in Nepal. 


\section{References}

Arnstein, S.R. (1969) 'A ladder of citizen participation', Journal of the American Institute of Planners 35(4): 216-24.

Eales, K., Blackett, I., Siregar, R. and Febriani, E. (2013) Water and Sanitation Program (WSP) report: Review of Community-Managed Decentralized Wastewater Treatment Systems in Indonesia, Washington, DC: World Bank.

Environment and Public Health Organization (ENPHO) (2010a) EcoSanRes 2: Nepal Node for Sustainable Sanitation - Project Document (2009-2010), Kathmandu, Nepal: ENPHO.

ENPHO (2010b) DEWATS FOR SUNGA COMMUNITY - Sunga, Madhyapur Thimi, Nepal, Factsheet on DEWATS, Kathmandu, Nepal: ENPHO.

ENPHO (2010c) DEWATS FOR SRIKHANDAPUR COMMUNITY - Srikhandapur, Dhulikhel, Nepal, Factsheet on DEWATS, Kathmandu, Nepal: ENPHO.

Gutterer, B., Sasse, L., Panzerbieter, T. and Reckerzügel, T. (2009) Decentralised Wastewater Treatment Systems (DEWATS) and Sanitation in Developing Countries: A Practical Guide, Loughborough, UK: Water, Engineering and Development Centre (WEDC).

IRIN (2012) 'Nepal: looking to low-tech wastewater treatment' [online], IRIN News, <www. irinnews.org/fr/report/94818/nepal-looking-to-low-tech-wastewater-treatment> [accessed 3 January 2014].

Lüthi, C., Morel, A., Tilley, E. and Ulrich, L. (2011) Community-Led Urban Environmental Sanitation Planning: CLUES, Dūbendorf, Switzerland: Eawag-Sandec/WSSCC/UN-HABITAT.

Muzzini, E. and Aparicio, G. (2013) Urban Growth and Spatial Transition in Nepal: An Initial Assessment, Washington, DC: World Bank.

Sherpa, M.G., Lüthi, C. and Koottatep, T. (2012) 'Applying the Household-Centered Environmental Sanitation planning approach: a case-study from Nepal', Journal of Water, Sanitation and Hygiene for Development 2(2): 124-32 <http://dx.doi.org/10.2166/washdev.2012.021>.

Tuladhar, B., Shrestha, P. and Shrestha, R. (2008) 'Decentralised wastewater management using constructed wetlands' in Beyond Construction. Use By All: A Collection of Case Studies from Sanitation and Hygiene Promotion Practitioners in South Asia, London, UK: WaterAid, IRC, WSSCC.

United Nations Population Fund (UNFPA) (2007) State of the World Population 2007: Unleashing the Potential of Urban Growth, New York: United Nations Population Fund.

WaterAid Nepal (2008) Fieldwork Paper: Ecological Sanitation Latrines - The experience of Nepal, Kathmandu, Nepal: WaterAid Nepal.

World Bank (2012) 'South Asian experts share experiences of rural water supply and sanitation programs' [press release], News, 10 October $2012<$ http://www.worldbank.org/en/news/ press-release/2012/10/10/south-asian-experts-share-experiences-of-rural-water-supply-andsanitation-programs> [accessed 3 January 2014].

\section{Website}

Google Maps, (2012) 'satellite photographs of Nepal'. Available at: <http://goo.gl/maps/OnfLD> ([Aaccessed: 3 January 2014]). 